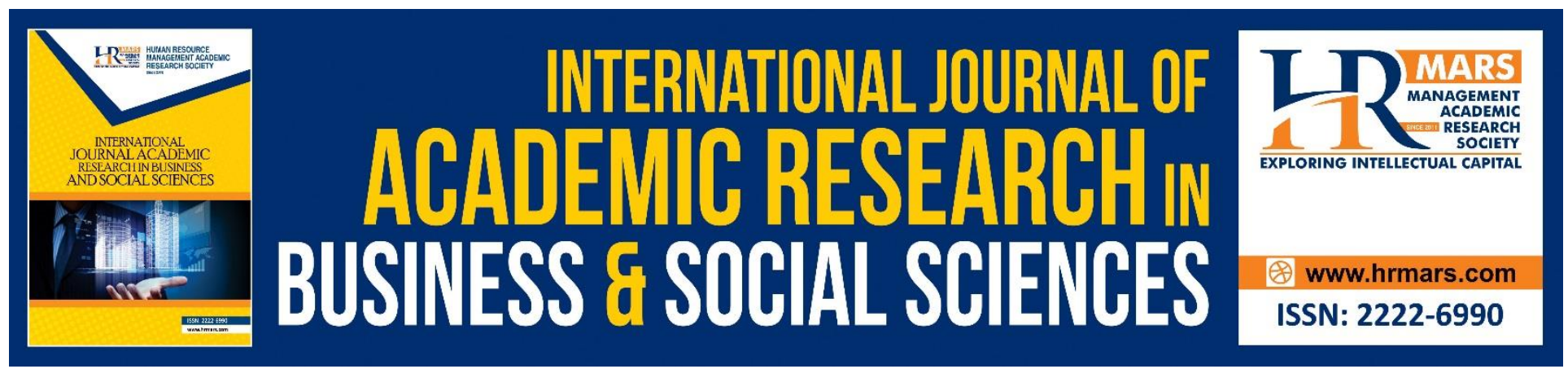

\title{
Technology-Assisted Career Counselling: Application, Advantages and Challenges as Career Counselling Services and Resources
}

\author{
Zaida Nor Zainudin, Siti Aishah Hassan, Mansor Abu Talib, Nor Aniza \\ Ahmad, Yusni Mohamad Yusop, Alia Sarah Asri
}

To Link this Article: http://dx.doi.org/10.6007/IJARBSS/v10-i11/8047

DOI:10.6007/IJARBSS/v10-i11/8047

Received: 02 September 2020, Revised: 27 September 2020, Accepted: 17 October 2020

Published Online: 06 November 2020

In-Text Citation: (Zainudin, et al., 2020)

To Cite this Article: Zainudin, Z. N., Hassan, S. A., Abu Talib, M., Ahmad, N. A., Yusop, Y. M., \& Asri, A. S. (2020). Technology-Assisted Career Counselling: Application, Advantages and Challenges as Career Counselling Services and Resources. International Journal of Academic Research in Business and Social Sciences. 10(11), 67-93.

Copyright: (c) 2020 The Author(s)

Published by Human Resource Management Academic Research Society (www.hrmars.com)

This article is published under the Creative Commons Attribution (CC BY 4.0) license. Anyone may reproduce, distribute, translate and create derivative works of this article (for both commercial and non-commercial purposes), subject to full attribution to the original publication and authors. The full terms of this license may be seen

at: http://creativecommons.org/licences/by/4.0/legalcode

Vol. 10, No. 11, 2020, Pg. 67 - 93

http://hrmars.com/index.php/pages/detail/IJARBSS

JOURNAL HOMEPAGE

Full Terms \& Conditions of access and use can be found at http://hrmars.com/index.php/pages/detail/publication-ethics 


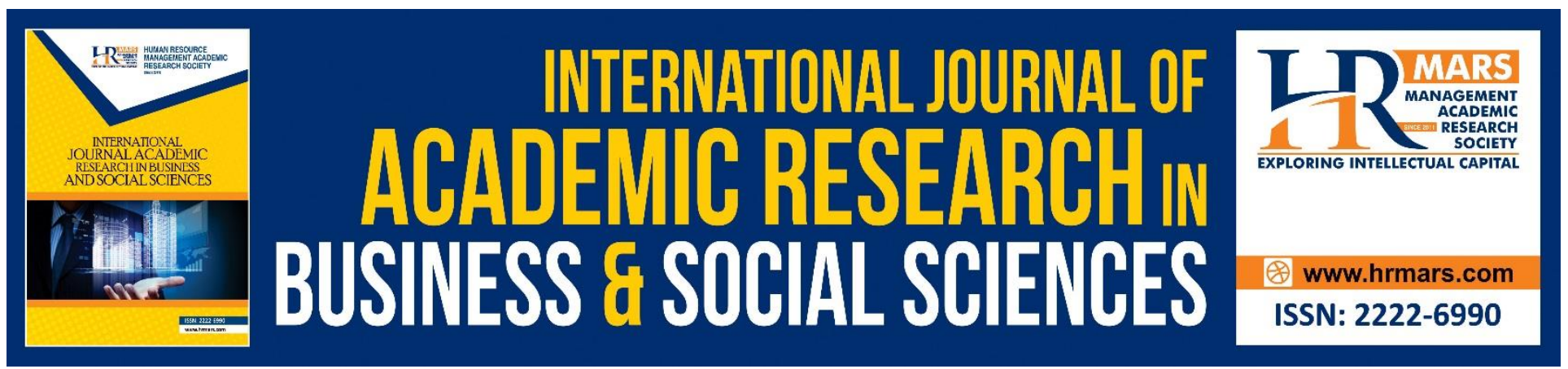

\title{
Technology-Assisted Career Counselling: Application, Advantages and Challenges as Career Counselling Services and Resources
}

\author{
Zaida Nor Zainudin, Siti Aishah Hassan, Mansor Abu Talib, Nor \\ Aniza Ahmad, Yusni Mohamad Yusop, Alia Sarah Asri \\ Faculty of Educational Studies, Universiti Putra Malaysia, Malaysia \\ Email: zaidanor@upm.edu.my, sitiaishahh@upm.edu.my,mansorat@upm.edu.my, \\ nor_aniza@upm.edu.my, yusni_my@upm.edu.my,gs53296@student.upm.edu.my
}

\begin{abstract}
The emergence of computer and ICT decades ago has gradually changes the lives of every individual in all parts of the globe. Through the use of internet and technology in career counselling services and resources, both counsellors and clients are affected, both positively and negatively, which can assist career counsellors and practitioners in finding ways to enhance their services. Hence, this systematic literature review paper will discuss on how technology-assisted career counselling is applied. The advantages and challenges were identified. Scopus, Science direct and Medline were searched to identify research published between 2010 and 2018 which had reporting about the application, advantages, challenges in technology-assisted career counselling services. A total 30 journal articles were selected for present a systematic review. The findings show that the advantages cover the expended reach of services, constant access, immediate response, generating info gathering and also the use of audio-visual. The challenges identified are self-limited thinking, lack of awareness, limited access to internet, digital illiteracy, and quality of information, confidentiality and client's urgent needs. Implications of this paper is also discussed on how the role of career counsellors and practitioners; researchers and educators are emphasized in order to enhance counselling services for current and future use and references.
\end{abstract}

Keywords: Career Counselling, Computer-Assisted, Technology-Assisted, Online Counselling, Advantages.

\section{Introduction}

Career aspect is a lifelong process and is considered as one of the most important aspects in the lives of every individual being. Since our perceptions of career start all the way back to primary school years, it is not at all shocking to say that career issues are most probably what individuals have to often deal with. These career issues include those such as career indecision, career planning, career satisfaction and so forth. For this reason, career counselling services are provided for individuals who 
are facing one of these issues where career counsellors are responsible for many things which include clarifying, identifying and implementing career decisions, and assisting these individuals (clients) to adapt to those decisions (Amudson et al., 2008, as cited in Papakota, 2016). A different definition to how career counselling works is explained from the six core areas that are frequently addressed during career counselling (National Career Development Association, 2009, as cited in Osborn et al., 2014). These six core areas include "learning about self, obtaining occupational and educational information, enhancing decision-making and career planning, coping with career challenges and transition issues, conducting a job search, and applying for training and further education" (p. 258).

The use of computer and ICT in career counselling is not at all recent and it dates back to the first use of computer program in counselling services in 1960s. The emergence of ICT has greatly changes the way we live and the world that is more fast-paced and unpredictable. As Maree (2017) stated, as cited in Haberstroh, Rowe and Cisneros (2009), the emergence of internet, ICT and social networks is changing the lifestyle, learning modes and career future of the young generation who are evidently different from the older generations such as the baby boomers. Nevertheless, for both young and older generation these days, the internet has gradually become an integral and important part of everyone's lives where it is used as a medium of communication, entertainment and information gathering. Hence, this increasing use and reliance on internet and technology has created opportunities for career counsellors and practitioners to enhance and improve their services to all (Zainudin et al., 2019).

Technology-assisted career counselling is provided in many forms and for different purposes. As a career resource such as career sites and online career assessments, it is provided as a tool for information gathering and job search. On the other hand, as a different career counselling method from the face-to-face counselling, it is provided as a way for individuals to seek for help and guidance from counsellors in a virtual world (e.g. telephone counselling, email counselling, and online chat). Although both of these forms of career services are important, it seems that full integration of the ICT into the career guidance practice is still far from ready (Bright, 2015).

Hence, this review paper is written to discuss and explore on how prevalent the use of technology and ICT in career counselling services, then on the advantages that make attractive of these services to specific individuals, and finally on the challenges that these services face that can limit their usefulness and effectiveness in providing services for all. Last but not least, this paper will also discuss on the implication of what has been explored on the topic of career counselling via technology which emphasizes on how career counsellors and practitioners, researchers and educators are responsible in improving the lives of the digitalized society. In general, this paper will explore on how career counselling via internet and ICT can be an alternative approach to counselling other than face-to-face counselling, or on how these two services can work together to enhance the overall counselling experiences. As Bright (2015) clearly stated in his article, "career development and ICT are now intimately intertwined, and it is time to work out how we can best get along and make the most of it, and to stop ignoring or resisting the potential of ICT to transform our practice" (Bright, 2015).

\section{Objectives}

The objective of this review paper is to explore and investigate the alternative approach to career counselling via technology and ICT, its application, advantages as well as challengers when delivering 
INTERNATIONAL JOURNAL OF ACADEMIC RESEARCH IN BUSINESS AND SOCIAL SCIENCES Vol. 10, No. 11, 2020, E-ISSN: 2222-6990 @ 2020 HRMARS

these services. Hence, the questions below will provide the objectives of this study on the main ideas and contexts that will be highlighted in this review paper.

1. How does technology and internet currently being applied in career guidance and counselling among different group of individuals?

2. What are some of the main advantages of using technology and internet in career counselling that are able to influence certain individuals to seek for these services?

3. What are some of the main challenges of using technology and internet in career counselling that limit the effectiveness and usefulness of the services provided?

\section{Methodology}

The systematic literature review was first initiated with key words that are relevant to the main objectives of this review paper. A list of other key words was included so to limit the literatures to a smaller number that can allow further filtration in order to derive the most suitable and relevant literatures. The objectives of this systematic literature review served as a guide when searching for literatures that are appropriate to the main context in this review paper.

\section{The Search Strategy}

Journal articles were selected through the use of SCOPUS database for the purpose of this review. The searching process began with a list of key terms which are 'career', 'counselling', 'counseling', 'computer-assisted', 'cyber', 'technology' and 'social media'. Next, the search was limited from the year 2013 until 2018 as to review some of the most recent journal articles publications. Afterwards, the search was further limited to include only articles that satisfy the subject areas 'Psychology', 'Social Sciences' and 'Arts and Humanities'. Then, due to the large number of articles remained in the search, the key terms were further extended and limited into the specific key words that reviewer wished to review. These additional key terms are 'career counselling', 'career counseling', 'internet', 'technology', 'social media', 'computer-based career intervention' and 'computer-based career assessment'. Finally, the identified articles were all reviewed and chosen to obtain exactly 8 articles after 10 articles were excluded from the review process. The searching method used is known as to be the inclusion and exclusion criteria, tabulated in Table 1 and 2, to search for the most appropriate literature reading for this review.

The key terms used were able to extract as many as 250 articles in the initial searching process. Such amount of articles identified were possibly due the overlapping research articles made on the topic from different subject areas and fields. Hence to reduce these number, inclusion criteria was used by filtering the publication year and subject areas. The search was limited from the publication year 2013 until 2018 where it was able to identify exactly 106 articles, then the three subject areas to get 63 articles. Due to the large number of articles still remained in the list, additional key terms were included which resulted to 19 articles. Following this, the exclusion criteria was used by reviewing each of the 19 articles listed to select a minimum of 10 articles that are most appropriate to the objectives of this paper.

However, only eight articles were found to be most fitting which then caused the reviewer to search for at least another twelve articles. Fortunately, the SCOPUS database has a feature that state and recommends articles that are cited by the articles chosen by the users. Therefore from the list of articles cited, reviewer was able to choose twenty-two articles that best fit the objectives of this paper along with the other eight selected articles. A much simpler and easily understood method in 
INTERNATIONAL JOURNAL OF ACADEMIC RESEARCH IN BUSINESS AND SOCIAL SCIENCES

Vol. 10, No. 11, 2020, E-ISSN: 2222-6990 @ 2020 HRMARS

understanding this inclusion and exclusion criteria can be seen in Figure 1 on the flow chart of article selection. Finally, a total of 30 articles selected were reviewed where relevant details and findings are summarized as shown in Table 3. The articles were also downloaded from their respective publication servers and were saved in PDF forms so to ease the reviewer when reviewing all of the selected articles.

Table 1. The inclusion criteria

\begin{tabular}{|c|c|c|}
\hline $\begin{array}{l}\text { Inclusion } \\
\text { Criteria }\end{array}$ & Particulars & $\begin{array}{l}\text { Literatures } \\
\text { identified }\end{array}$ \\
\hline Key terms & $\begin{array}{l}\text { Career, Counselling, Counseling, Computer- } \\
\text { assisted, Cyber, Technology, Social media }\end{array}$ & 250 \\
\hline Year & 2013 to 2018 & 106 \\
\hline $\begin{array}{l}\text { Subject } \\
\text { area }\end{array}$ & $\begin{array}{l}\text { Psychology, Social Sciences, Arts and } \\
\text { Humanities }\end{array}$ & 63 \\
\hline $\begin{array}{l}\text { Additional } \\
\text { key terms }\end{array}$ & $\begin{array}{l}\text { Career counselling, Career counseling, } \\
\text { Intemet, Technology, Social media, } \\
\text { Computer-based career intervention, } \\
\text { Computer-based career assessment }\end{array}$ & 19 \\
\hline $\begin{array}{l}\text { Additional } \\
\text { journal } \\
\text { source }\end{array}$ & $\begin{array}{l}\text { Educational and Informational Technologies } \\
\text { Joumal of Cases on Information Technology } \\
\text { Education and science joumal } \\
\text { Transforming Government: People, Process } \\
\text { and Policy } \\
\text { Computers in Human Behavior } \\
\text { British Joumal of Guidance \& Counselling } \\
\text { Australian Joumal of Career Development } \\
\text { Joumal of Career Assessment } \\
\text { Educational Media Intemational } \\
\text { Clinical Social Work Joumal } \\
\text { SAGE Open } \\
\text { Joumal of Career Development } \\
\text { International Joumal for the Advancement of } \\
\text { Counselling } \\
\text { International Joumal of Innovation and } \\
\text { Leaming } \\
\text { The Career Development Quarterly }\end{array}$ & 22 \\
\hline
\end{tabular}


INTERNATIONAL JOURNAL OF ACADEMIC RESEARCH IN BUSINESS AND SOCIAL SCIENCES Vol. 10, No. 11, 2020, E-ISSN: 2222-6990 @ 2020 HRMARS

Table 2. The exclusion criteria

\begin{tabular}{|c|c|c|c|}
\hline $\begin{array}{c}\text { Exclusion } \\
\text { Criteria }\end{array}$ & Particulars & & \\
\hline \multirow[t]{10}{*}{ Source } & Rehabilitation Counseling Bulletin & 1 & \multirow{10}{*}{$=10$} \\
\hline & Travail Humain & 1 & \\
\hline & Joumal of Information Systems Education & 1 & \\
\hline & South African Journal of Education & 1 & \\
\hline & $\begin{array}{l}\text { American Joumal of Drug and Alcohol } \\
\text { Abuse }\end{array}$ & 1 & \\
\hline & Egitim ve Bilim & 1 & \\
\hline & $\begin{array}{l}\text { 20th Americas Conference on Information } \\
\text { Systems }\end{array}$ & 1 & \\
\hline & Drustvena Istrazivanja & 1 & \\
\hline & Psicologia Educativa & 1 & \\
\hline & $\begin{array}{l}\text { Proceedings of the Human Factors and } \\
\text { Ergonomics Society }\end{array}$ & 1 & \\
\hline
\end{tabular}


INTERNATIONAL JOURNAL OF ACADEMIC RESEARCH IN BUSINESS AND SOCIAL SCIENCES Vol. 10, No. 11, 2020, E-ISSN: 2222-6990 @ 2020 HRMARS

\section{INCLUSION CRITERIA}

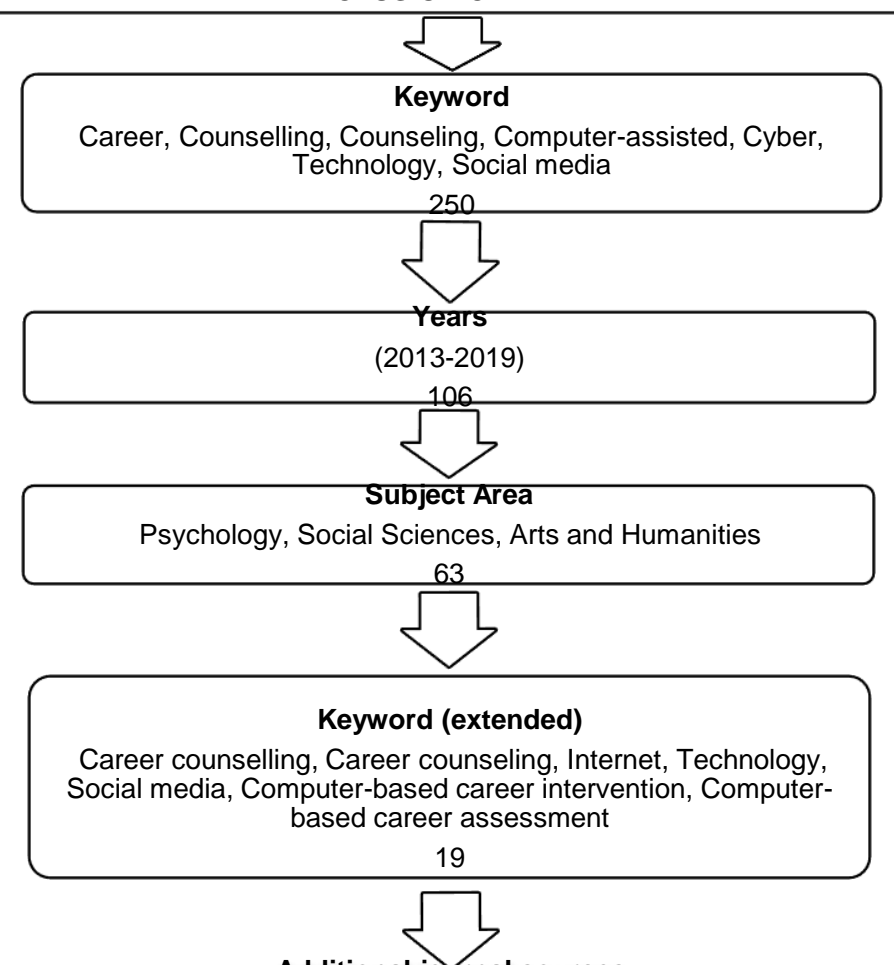

\section{Additional journal sources}

Educational and Informational Technologies ,Journal of Cases on Information Technology, Education and science journal, Transforming Government: People, Process and Policy, Computers in Human Behavior, British Journal of Guidance \& Counselling, Australian Journal of Career Development, Journal of Career Assessment, Educational Media International, Clinical Social Work Journal, SAGE Open, Journal of Career Development, International Journal for the Advancement of Counselling, International Journal of Innovation and Learning, The Career Development Quarterly

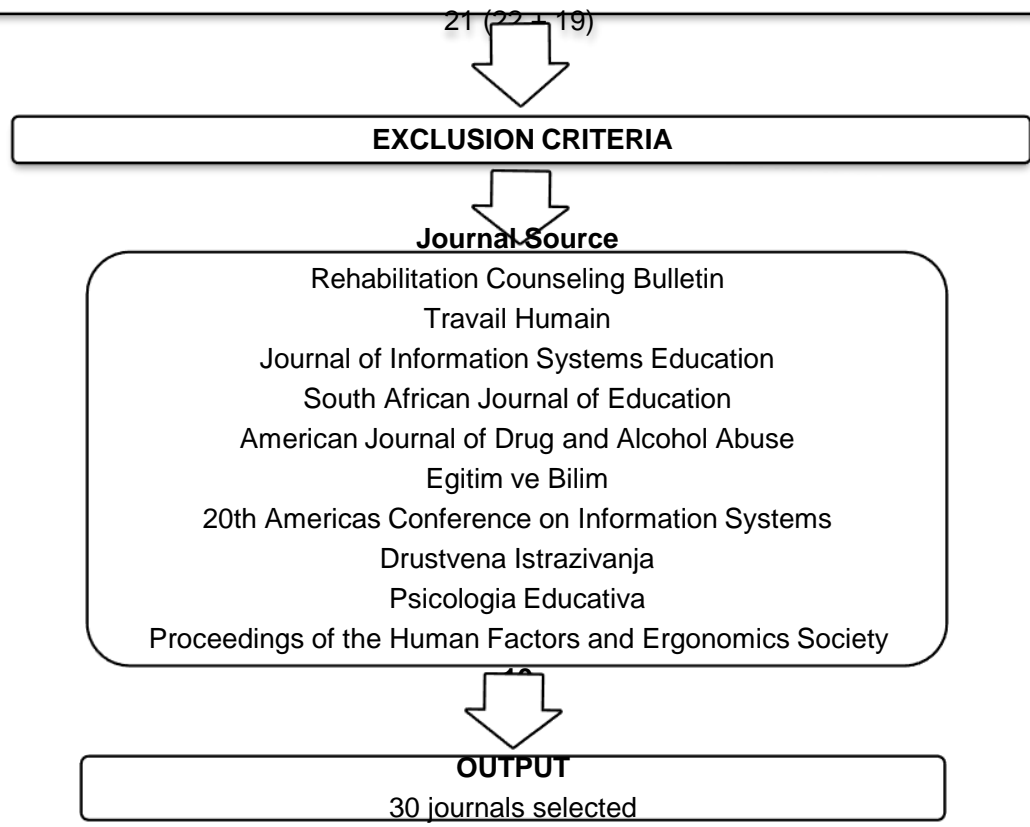

Figure 1. Flow chart of article selection 
INTERNATIONAL JOURNAL OF ACADEMIC RESEARCH IN BUSINESS AND SOCIAL SCIENCES

Vol. 10, No. 11, 2020, E-ISSN: 2222-6990 (C) 2020 HRMARS

\section{Findings From Literature Review}

The selected journal articles from the search strategy are summarized as shown in Table 3 . The literatures are presented by their authors, publication years, title of journal, sample of the study conducted (if any) and finally the findings in each literature that are relevant to the objectives of this systematic literature review.

Table 3. Summary of selected literatures

\begin{tabular}{|c|c|c|c|c|}
\hline & Author (Year) & Title of Journal & Sample & Relevant Findings \\
\hline 1 & $\begin{array}{l}\text { Nooshin } \\
\text { Pordelan, } \\
\text { Ahmad } \\
\text { Sadeghi, } \\
\text { Mohammad } \\
\text { Reza Abedi, \& } \\
\text { Marjan Kaedi } \\
\text { (2018) }\end{array}$ & $\begin{array}{l}\text { Educational and } \\
\text { Informational } \\
\text { Technologies }\end{array}$ & $\begin{array}{l}45 \text { university } \\
\text { students are } \\
\text { separated into } \\
\text { three groups: } \\
\text { face-to-face } \\
\text { group, online } \\
\text { intervention } \\
\text { group and } \\
\text { control group }\end{array}$ & $\begin{array}{l}\text { The study found that the use of } \\
\text { online technology in career } \\
\text { counseling is considered effective } \\
\text { and can be utilized as alternative } \\
\text { method to career counselling. The } \\
\text { experiment conducted also showed } \\
\text { significant effect of using online } \\
\text { counselling on the career } \\
\text { development of students as } \\
\text { compared to other career variables } \\
\text { such as career decision-making. }\end{array}$ \\
\hline 2 & $\begin{array}{l}\text { Lent, R.W. } \\
\text { (2018) }\end{array}$ & $\begin{array}{l}\text { Career } \\
\text { Development } \\
\text { Quarterly }\end{array}$ & - & $\begin{array}{l}\text { The author highlight the role of } \\
\text { career development professionals } \\
\text { and vocational psychologists to have } \\
\text { the skills, knowledge and information } \\
\text { in catering to clients who are facing } \\
\text { the current working world and } \\
\text { technologically modern economy } \\
\text { that is less stable, secure and } \\
\text { predictable }\end{array}$ \\
\hline 3 & $\begin{array}{l}\text { Glasheen, } \\
\text { McMahon, } \\
\text { Campbell, } \\
\text { Rickwood, \& } \\
\text { Shochet, (2018) }\end{array}$ & $\begin{array}{l}\text { International } \\
\text { Journal for the } \\
\text { Advancement of } \\
\text { Counselling }\end{array}$ & $\begin{array}{l}33 \text { secondary } \\
\text { school principle. }\end{array}$ & $\begin{array}{l}\text { The study found that the } \\
\text { technological competency and } \\
\text { acknowledged the benefits of using } \\
\text { technology in the counselling } \\
\text { process. The principals were } \\
\text { generally supportive of the provision } \\
\text { of online school counselling, } \\
\text { Although their major concern was the } \\
\text { need for more counsellors and the } \\
\text { impact on the } \\
\text { workload of current counselling staff }\end{array}$ \\
\hline 4 & $\begin{array}{l}\text { Galliott, N. } \\
\text { (2017) }\end{array}$ & $\begin{array}{l}\text { Journal of } \\
\text { Psychologists and } \\
\text { Counsellors in } \\
\text { Schools }\end{array}$ & $\begin{array}{l}706 \text { high school } \\
\text { students from } \\
12 \text { schools in } \\
\text { New South } \\
\text { Wales, Australia }\end{array}$ & $\begin{array}{l}\text { Majority of students are unaware of } \\
\text { the availability of online career } \\
\text { guidance services provided that are } \\
\text { targeted for use for them at schools. } \\
\text { This, along with other possible }\end{array}$ \\
\hline
\end{tabular}


INTERNATIONAL JOURNAL OF ACADEMIC RESEARCH IN BUSINESS AND SOCIAL SCIENCES

Vol. 10, No. 11, 2020, E-ISSN: 2222-6990 (C) 2020 HRMARS

Male: 251

Female: 455

5 Wessels, C.J.J., South African Diale, B.M. Journal of (2017)

Education

6 Paterson, Laajala, \& Lehtela, (2017)

7 Poncy, Kim, Ramos, \& Lopez, (2017)

8 Papakota, A. (2016)

Industry and

Higher Education

Three participants,

Age: 17

Male: one

Female: two

British Journal of Guidance \&

Counselling

Journal of Career Assessment

Industry and
Higher Education
student Male: female: 20 high school students in South Africa

9
Nota, L.,
Santilli, S.,
Career
Soresi, S. (2016)
Development
Quarterly

10 John, Udofia, Udoh, \& Anagbogu (2016)

Age: $\quad 26-60$

Age: 13

Male: 87

Female: 113

60 senior secondary school students were selected
Age: 9-12 factors, subsequently causes little relation between students' career certainty and listed career resources sites.

Facebook as the largest site for social networking serves as a supporting tool or instrument, along with the use of career assessment tools, in exploring and enhancing career constructions of young adolescents.

28 counselling The study found that there is four

6
different orientations toward online counseling which is technical, organization-centered, counselingethical and developing orientation. The study found that controlling for features of FB use, adult attachment security and authenticity would make significant and incremental

The author focuses on the use of computer-aided career guidance at a university in Greece that is considered as a valuable aid in assisting students and graduates when seeking career information, tools and requirements among others.

200 middle The finding from the study on preschool students adolescents in middle schools stated from public that students, regardless of gender, schools in show better career adaptability northeast Italy (which comprises of four dimensions: from two concern, control, curiosity and confidence) and life satisfaction when using online interventions as compared to those using traditional guidance intervention method.

The study found that the e-career Guidance system have significant difference in vocational selfawareness and career awareness. 
INTERNATIONAL JOURNAL OF ACADEMIC RESEARCH IN BUSINESS AND SOCIAL SCIENCES

Vol. 10, No. 11, 2020, E-ISSN: 2222-6990 @ 2020 HRMARS

11 Omeje, Eze, \&
Egeonu, (2016)

12 Glasheen, Shochet, \&

Campbell

(2016)

13 Argyris \& Xu

(2016)

14 Bright, J.E.H. (2015)

15 Zeren (2015)
SAGE Open

ish Journal of

Guidance \&

Counselling

Computers in Human Behaviour

British Journal of Guidance and Counselling

school in Akwa

Ibom State

200

undergraduate students from

five federal

universities

from South East

Nigeria

Male:100

Female: 100

215 students

from

government

and non-

government

school in South

East

Queensland

Male:103

female:112

260 students

from university, college and community school.

Age: 17-24

male: 127

female: 133

-

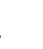

Counselling

15 Zeren (2015)

Education and

Science
Male:9

Female: 12
The study show that the students is awareness of the e-counselling for career information dissemination is high. They are very aware of the use of the e-counselling opportunities. The result also show that the high rate for the use of e-counselling is the final year student where is unemployed.

The study found out that there is no significant different between the gender in the likely intention to seek online help. While the student with psychological distress had a preference for online counselling. The student who choose online counselling is more toward to discuss sensitive issues than career issues.

The study found that Facebook is unique affordances for self-efficacy development. It is one of the effective sources of self-efficacy for career development.

The study found that although the use of internet is prevalent and constantly increasing in career counselling, it is still not adequately and fully utilized and researched for better and less chaotic career development among individuals. The use of ICT in career development should not be considered as an either-or method to counselling approach when in fact its benefits are far reaching for use in career counselling.

The study found that the problems and satisfaction are quite similar in 
INTERNATIONAL JOURNAL OF ACADEMIC RESEARCH IN BUSINESS AND SOCIAL SCIENCES

16

$\begin{array}{ll}\text { Bimrose, } & \text { British Journal of } \\ \text { Kettunen, \& } & \text { Guidance \& } \\ \text { Goddard (2015) } & \text { Counselling }\end{array}$

17 Mishna, Bogo, \& Sawyer (2015)

18 Vertsberger \& Gati, (2015)

19 Anthony (2015)

\section{Clinical Social Work Journal}

Journal of Career Development
British Journal of Guidance \& Counselling
20 Sampson Jr., J.P., Makela, J.P. (2014)
International

Journal for

Educational and

Vocational

Guidance
24 interns and

262

undergraduate students

300 young adults who had not yet formulated their plans for the future or chosen a field of study.

Age: 18 above

Male: 117

Female: 183 face-to-face and online clients. The career development concern is one of the common problem that face by client that go for face-to-face and online counselling.

The study mentioned that the complexity of skills that need for the practitioners to effectively design, develop and deliver technologyenabled career services.

The study found that the cyber counselling had make the client feel less inhibited and it easier them to disclose their feelings and issues. Some of the challenges were discuss in this study.

The study show that young adult intentions to seek help were positively correlated with their career decision-making difficulties and with their career decision status. They are more inclined to seek help from the sources that is easier for them to access such as family, friend and internet.

The study showed that The importance of understanding how cyber culture impacts on clients lives and therefore their mental health needs, creating a need for empathy around living online in order to understand client issues in the modern world that are brought into therapeutic sessions.

The study was able to identify ethical issues that challenge and limit the usage of internet and technology for career resources and career counselling services. These issues include social equity, resource, and service issues. 
INTERNATIONAL JOURNAL OF ACADEMIC RESEARCH IN BUSINESS AND SOCIAL SCIENCES

Vol. 10, No. 11, 2020, E-ISSN: 2222-6990 @ 2020 HRMARS

21 Osborn, D.S., Canadian

Kronholz, J.F., $\quad$ Psychology

Finklea, J.T.,

Cantonis, A.M.

(2014)

22 Amritesh, Misra, \& Chatterjee

(2014)

23

$\begin{array}{ll}\text { Wong, Kwan, } & \text { International } \\ \text { Leung, \& Wang, } & \text { Journal of } \\ \text { (2014) } & \text { Innovation and } \\ & \text { Learning }\end{array}$

24 Ryan \& Hopkins, (2013)

25 Glasheen, Campbell, \& Shochet (2013)

26 Howieson \& Semple, (2013)
Australian Journal

18 Year 12

of Career

Development

Australian Journal
of Guidance and
Counselling

Transforming

People, Process

and Policy

63 university students

Male: 23

Female: 40

school leavers

210 school

counsellors

from the

worldwide

Age: 20-69

Male: 59

Female: 151

British Journal of 250 pupils

Guidance \&

Counselling
The study clarifies and emphasizes the relevant use of technology for better career decision-making process and job searching, which are both explained through the use of Cognitive information-processing theory (CIP).

The study found that the demands of the labour market had increase the need of the counselling service in for individual career guidance requirement. The online counselling will be one of the intervention that meet the requirement.

The study found that the students and teacher were benefits from using Facebook on learning and teaching. The potential benefits of social networking for students are not only limited to academic development but also extended to personal/social development and career development.

The study found out that. Strong social support networks are an important factor determining career development and study success, especially for young people from disadvantaged backgrounds

The study found out that counsellor will accept the online counselling if the students is accepted it use in school setting. The counsellor still lack of confidence in understanding the ethical and legal implications of online counselling.

The study found out that minority pupils to be more active in their career planning by seeking direct with professional career guidance rather than using the accessing of career website 
INTERNATIONAL JOURNAL OF ACADEMIC RESEARCH IN BUSINESS AND SOCIAL SCIENCES

Vol. 10, No. 11, 2020, E-ISSN: 2222-6990 (C) 2020 HRMARS

27 Harris-

Bowlsbey,

(2013)

28

Adebowale \& International

Popoola, (2011) Journal for the

Advancement of

Counselling

Development

Quarterly

172 university students and 100 members of staff of university
29 Gati \& AsulinPeretz, (2011)

Journal of Career Assessment

30

Haberstroh, S., Rowe, S., \& Cisneros, S. (2009)
Journal of Cases

on Information

Technology
The study found that the computerassisted career guidance system had improve over the years and it is accepted as one of the effective tools for career guidance practice.

The study students identified potential online guidance and counselling needs as being mainly related to academic/educational interests; specifically, career planning, problem-solving skills and acquiring effective study skills. There is also some limitation were discussed in the study.

The study stated that online intervention tools will not replace face-to-face human counselling but the online tools will help the career counselling process to be more effective and efficient.

The study highlights on the use of online technology in both serving for online career information and online chat career counselling service in an anonymous university through its office of career services. The online service is explained according to its application, ethics and limitations among others. 
INTERNATIONAL JOURNAL OF ACADEMIC RESEARCH IN BUSINESS AND SOCIAL SCIENCES Vol. 10, No. 11, 2020, E-ISSN: 2222-6990 @ 2020 HRMARS

\section{Discussion}

\section{Application of Technology and Internet in Career Guidance and Counselling}

The use of technology and internet for career purposes are widespread and it covers various applications from not only in delivering alternative method to face-to-face career counselling, but also used as career assessments, interventions, career information gathering, career planning and career decision-making among others. Many of these services that utilized the benefits of ICT in improving career aspects of individuals are those such as online chatroom, online support group or online video conferencing for career counselling sessions; also currently applied are online websites, social media and mobile applications that focus on career information gathering, career assessments, career indecisions and so forth that can improve career development and adaptability among individuals who are seeking for assistance.

Przeworski and Newman (2004), as cited in Osborn et al. (2014), stated that there exist myriad of technological options that are used for cognitive restructuring and anxiety, among many, in pursuit for career decision-making process. An example used is in alleviating social phobia and generalised anxiety disorder symptoms through cognitive restructuring using handheld technology device. In a different article by Haberstroh, Rowe and Cisneros (2009), an institution, from a recent study, utilizes online counselling in screening and intervening suicidal cases among students. This shows that online counselling services can potentially be used on clients who are facing critical issues such as suicidal tendencies, depression and anxieties. Also in an academic setting at a high school in Italy, online programs are offered as a way to improve career planning and decision making among student adolescents especially among boys, initially intended due to the increased dropout rate among boys in the first years of high school (Miller, Schweingruber, \& Brandenburg, 2001; MIUR, 2014, as cited in Nota, L., Santilli, S., \& Soresi, S., 2016). Nevertheless, a study by Hargittai and Shafer (2006) and Rainie (2010), as cited by Nota, Santilli and Soresi (2016), showed that online programs or technology in general (such as videos or simple interactive computer activities) are perceived to be not only effective and appropriate for boys, but also girls. Hence, it can be said that technology offers the younger generation, regardless of gender identities, with possibilities to be actively and positively involved in the their respective career aspects.

\section{Online Program}

The same article by Nota, Santilli and Soresi (2016) presented online programs that can be utilized as alternative to career counselling method or as career intervention programs which are referred to as the Computer Assisted Career Guidance (CACG). Four of these CACGs that are aimed for school students, or the youth in general, is DISCOVER (American College Testing Program, 1991), Believe It: A Career Development Intervention for Young Women (Kovalski \& Horan, 1999), Mapping Vocational Challenges (Turner \& Lapan, 2005) and Computer-Assisted Career Group Guidance (Bozgeyıklı \& Dog`an, 2010). The first program, DISCOVER, provides an array of occupational information that can be matched to students' self-assessments while the second program, Believe It: A Career Development Intervention for Young Women are developed with focus to change irrational career beliefs through two 50-minute meetings. These irrational beliefs are those such as "for every person, there is only one job in the world that will lead to happiness" and "(d) certain jobs are more appropriate for men, whereas other jobs are better suited to women" (Nota, Santilli \& Soresi, 2016, p. 6). On the other hand, the third and fourth program are Mapping Vocational and Challenges, and Computer-Assisted Career Group Guidance where the former comprises of three modules of career 
INTERNATIONAL JOURNAL OF ACADEMIC RESEARCH IN BUSINESS AND SOCIAL SCIENCES Vol. 10, No. 11, 2020, E-ISSN: 2222-6990 @ 2020 HRMARS

exploration, career mapping and interpretation module while the later comprises of three steps which are presenting meaning of interests, skills and other related occupational terms, then for students to focus on these skills and interests, and lastly to relate to students' career and educational preferences and to provide them with adequate information to make decisions. Furthermore, the next program that can be found in the past for career intervention is Education and career exploration system (ECES). ECES is one of the program that develop by the IBM Corporation under consultancy of Donald Super (Harris-Bowlsbey, 2013). This program is helping the individual to explore their selfconcept in the exploration stages that propose by Super then it will help them to look on the suitable occupation and education alternatives. Picture will showed for the purpose of more realistic view of each occupation's daily task and setting (Harris-Bowlsbey, 2013).

\section{New Technologies and Artificial Intelligence}

At a different school setting at Aristotle University of Thessalokini (AUTH) in Greece, Europe, the Career Service Office (CSO), through its counselling service, demonstrated the application of new technologies in $\mathbf{2 0 0 8}$ with an easy-to-use guide, the CD-ROM guide. This application is referred to as the Career Counseling @ Career Office of Aristotle University of Thessaloniki where it "comprises of introduction, self-awareness, information, decision-making, goal setting, lifelong learning, selfpresentation, job searching in Greece and abroad, and job finding" (Papakota, 2016, p. 328-329). In terms of developing new technologies for career counselling purposes, Bright (2015), in his article, also considers the possibilities of using the Holographic technology in developing holographic counselling sessions. Hence, the technology of artificial intelligence cannot be ruled out from this topic discussion. Lent (2018) cited an article from Nutt (2017) where it discusses "Chatbots" that utilizes artificial intelligence in stimulating human dialogue. While it is considered as tools that offer life coaching, companionship and mental health support, Chatbots, according to Lent (2018), can also be used its benefits and designed as aids in career aspects such as in helping users to interpret assessment results. Further according to Lent, "such technological supports may be able to assist with some of the more routine aspects of career planning or change, while human service providers might then have more time to help with particular decisional difficulties or with more complex career problem scenarios" (e.g. depression, relational tensions, job search struggles following job loss)(p. 217).

\section{Social Media}

A different form of technology is also applied for use for career development purposes. Osborn et al. (2014) states the use of social media such as Facebook, Linkedln, blog and virtual career fairs in job search. In fact, Facebook has been widely used, both formally and informally, for career development especially among the youth and young adolescents who are the majority of Facebook and other social media users. This statement was supported by Wong, Kwan, Leung, \& Wang, (2014) article. The group that form in Facebook can be one of the interest group that help student to prepare their career development (Wong, Kwan, Leung, \& Wang, 2014). According to Wessels and Diale (2017), Facebook are used for self-disclosure (Bazarova \& Choi, 2014), also for satisfying the need to be belonged and as a self-presentation (Nadkarni \& Hofmann, 2012; Argyris \& Xu, 2016) and finally for exploring personal and social identities (Barker, 2009; Zhao, Grasmuck \& Martin, 2008). Further in the study by Wessels and Diale (2017) on South African counselling clients, the Facebook serves as prevalent and benefiting tools for these clients in pursuit of developing a new and positive 
INTERNATIONAL JOURNAL OF ACADEMIC RESEARCH IN BUSINESS AND SOCIAL SCIENCES Vol. 10, No. 11, 2020, E-ISSN: 2222-6990 @ 2020 HRMARS

perspective about themselves and hence not opting for online career assessments that are evident to be culturally biased towards the cultures in Western and European countries. According to Argyris and $\mathrm{Xu},(2016)$, Facebook is one of the the effective source of self-efficacy for career development. The affordance that provide by Facebook such as vitual people watching and affordance of garnering social support is the important sources for improving self-efficacy of the students. It help to gain vicarious experieces and social persuasions (Argyris \& Xu, 2016).

Furthermore, one of the universities in Hong Kong uses Facebook as one of their career development services. Using Facebook to provide the career information for their students helped them to plan for their future career. According to Wong, Kwan, Leung, and Wang (2014), Facebook contains a large number of professional groups. Student from the university should take advantage to join a particular group for getting further information from the profession (Wong, Kwan, Leung, \& Wang, 2014). The social capital online is associated with aspiration toward occupation achievement, leadership, and education but it does not sure that the individual or the student will get the confidence and the abilities to find the correct career search and the decision-making process. The exposure to the occupational possibilities and identities may be the one who make the Facebook user to be more confident and it can be done by interaction with the diverse online users who is work from the different field (Poncy, Kim, Ramos, \& Lopez, 2017). However, according to Poncy, Kim, Ramos, and Lopez (2017), found out that the large number of the friendship network in Facebook is not necessarily promote understanding and efficacy that facilitate the appropriate career-related choice. It must be together with controlling the features of Facebook use, adult attachment security and authenticity will make the student and individual build up the career confidence (Poncy, Kim, Ramos, \& Lopez, 2017). Use of Facebook is one of the tool for learning management and social integration. To successfully help student identify their life-long career development, education credentials and social network is the main key. Facebook is the tool that builds up their social network. It is not only is a sense of social cohesion and connectedness, it also use as prepare courses. The relationship of between the users is the point of increasing essential for long term career success (Ryan \& Hopkins, 2013).

\section{Online and Mobile Application}

Another form of technology that can be used for career development purposes are online and mobile application such as the app "IThoughts". Osborn et al. (2014) describes the apps iThoughts and "Unstuck" as tools to facilitate and enhance career decision making process for any individuals. Following this, meditation and mindfulness apps such as the "Headspace" can also help individuals in combatting negative metacognitions (e.g. stress, anxiety and depression) that can possibly limit their career decisions ((Evans et al., 2008; Cavanaugh et al., 2000 as cited in Osborn et al., 2014). There are also apps such as "FlipHead Thought-Stopping" to stop negative career thoughts and "DayOne Journaling" to help prepare clients to share their career problems through journaling between sessions.

\section{Advantages of Using Technology and Internet in Career Guidance and Counselling}

The cyber and online technology have served a great deal of benefits into improving especially healthcare services such as the counselling field. While many of the applications in counselling services are mediated and assisted using ICT, questions raised on how the growing use of technology 
INTERNATIONAL JOURNAL OF ACADEMIC RESEARCH IN BUSINESS AND SOCIAL SCIENCES Vol. 10, No. 11, 2020, E-ISSN: 2222-6990 @ 2020 HRMARS

can enhance and improve the services provided by counsellors for clients. These benefits and advantages can be seen through the use of technology in either career assessments, career tools or career counselling sessions that has the possibility to be as effective as the more traditional, face-toface career counselling services. Gati and Saka (2001), as cited in Galliott (2017), described that multiple studies have suggested the internet-based career assessment, for similar test, to be equivalent to paper-and-pencil administered versions. Lumsden et al. (2004), also cited in Galliott (2017), stated than computer-based format are preferable to most, for which Galliott (2017) claimed that the online users to these services are demonstrating greater self-focus and self-concern.

\section{Expanded Reach of Services}

The use of ICT for career counselling services and career development purposes also benefited the society at large for its longer range of opportunities in reaching out to all individuals. Sampson and Makela (2014) described that computer-aided counselling and guidance has the ability to expand its resources and services in reaching out to all communities especially the undeserved client populations while also "[transcending] geographic and physical barriers" (Sampson, 1998, p. 216, as cited in Sampson \& Makela, 2014, p. 137). Hooley et al. (2010) and Van Allen and Roberts (2011), as cited in Sampson and Makela (2014), also noted social media as being "fast, efficient and inexpensive tool for expanding the reach of career services" (p. 142). This is supported by Osborn et al. (2014), from a study by Berry and Lai (2014), who claimed that use of technology in services can reach a wider variety of clients, especially those who are incapable of seeking such services. Osborn et al. (2014) further added that social media also "create opportunities for psychologists to enhance service delivery and to connect with clients outside of the traditional office setting" (p. 258) while Haberstroh, Rowe and Cisneros (2009) concluded that, according to a research by Hass et al. (2008), online counselling interventions are helpful especially in student service programs as it provides greater outreach to all students which enables to create link between students and campus resources. Hence, it is possible to say that technology-assisted career counselling and guidance has the ability to expand its services to all individuals who may not have the privilege to seek for such services through the more traditional way. Furthermore, this was supported by the study of Amritesh, Misra, and Chatterjee (2014). Online counseling intervention were increased the opportunities for the university students. They are more easy and do not have to worry that will not getting seat for the counseling session. By using online intervention the student all can access the online counseling system (Amritesh, Misra, \& Chatterjee, 2014). Online intervention can be carried out at the time, place and pace most convenient for the individual (Gati \& Asulin-Peretz, 2011).

\section{Constant Access and Immediate Response}

Another advantage of technology-assisted or mediated career counselling would be its roundthe-clock access and immediate response which proves to be appealing to the younger generation. Bright (2015) stated that online counselling enables clients to feel that counsellors are "always listening and present", where such services offer 24/7 access with the use of internet, which is universal especially in western countries where the services can be accessed by users both at home or outside (p. 28). Bright (2015) also explained that the potentially immediate response and asynchronous feedback from the services allows ongoing career planning among the students who are the focal group that the article emphasizes on. Papakota (2016), in her study, provides positive feedback on AUTH's career counselling CD-ROM where the online platform enables the counselling 
INTERNATIONAL JOURNAL OF ACADEMIC RESEARCH IN BUSINESS AND SOCIAL SCIENCES Vol. 10, No. 11, 2020, E-ISSN: 2222-6990 @ 2020 HRMARS

process to be more relevant to the younger generation of digital natives. Therefore, it is evident that career counselling and guidance through online services is attracting more and more of the younger populations who are mostly comfortable with using technology in their everyday lives, hence drawing them to the services' constant access and immediate response. Anthony (2015) also stated that, from a study by Lehman and Berg (2007), the technologies now bring a lot of benefits to the practitioner and their clients. The internet and technologies helps creates course efficiency, provide flexibility and can be use at any time and situations and content (Anthony, 2015). The technology-assisted career counselling can be access and use in anytime that the client is free and can straight get support from the counsellor immediately. Client do not need to rush for the session especially when the counselling session is on the working hours or study time (Amritesh, Misra, \& Chatterjee, 2014). It consume a lot of time of the client. Online intervention system can help to reduce the time consume and more efficiency compare to face-to-face counselling (Amritesh, Misra, \& Chatterjee, 2014). The convenience of use and easy to accessibility to the career information and service make the online counselling mode is more utilization by the people nowadays (Omeje, Eze, \& Egeonu, 2016).

\section{Generator of Information Gathering}

Continuation on the rapid and constant use of the technology among the new generation, Bright (2015) described that this digital literacy leads to increase in extraction of information from the internet, which consequently enables its users to not be rigidly fixed to the "outdated attachment [of] singular career transition plan" but instead seek for "ongoing reinvention and planning" through skills development and training (p. 32). Bright (2015) continued that online career testing or assessments enable individuals to explore deeper and more rapidly their career interests, skills and abilities, which are provided through the vast of career information that are offered in the internet. Papakota (2016) also stated that, from a study by Sampson (1997), career information that are multimedia-based, as opposed to the more traditional-based, allows users to be more focused and engaged throughout their career planning and development. Indeed, information gathering for career development is important for any individuals, as also noted by Nota, Santilli and Soresi (2016) who explained that career decision-making among middle school students are supported by information they can gather which can vary from their personal characteristics, educational programs, and occupations. In fact, as Nooshin Pordelan et al. (2018) posited, the internet has become "the generator of knowledge and participatory information" (p. 2657) which proves that career information gathering are enhanced from the growing use of online technology among digitally literate population.

\section{Use of Audio-visual}

One more advantage of utilizing technology in career counselling services is its myriad methods in providing counselling process, especially on its use of audio-visual. Nota, Santilli and Soresi (2016) claimed that audio-visual method allows the counselling process to put more attention on important variables such as interest, values, ideas and skills. This is agreed by Nooshin Pordelan et al. (2018) who stated that "utilization of audiovisual instruments, such as slides, video tapes, and cartoons ... help [users to concentrate] on important variables in career development such as unreasonable ideas and skills" (p. 2669). Asides from audio-visual use in online counselling process, other form of method in providing online services to clients such as online asynchronous or synchronous text are also proven to be beneficial to clients. Nooshin Pordelan et al. (2018) stated 
INTERNATIONAL JOURNAL OF ACADEMIC RESEARCH IN BUSINESS AND SOCIAL SCIENCES Vol. 10, No. 11, 2020, E-ISSN: 2222-6990 @ 2020 HRMARS

that for clients to narrate their issues into online text, using their own language, provides them with opportunities to revive authorities to their narratives which as Goddard (2010) claimed, as cited in Nooshin Pordelan et al. (2018), assists counsellors in understanding clients' new concepts and selfunderstanding which are prevalent elements for efficient career development.

\section{Maximizing Career Counsellor Service}

One of the benefits of the online career assessment is helping the career counsellor and the client understand themselves more. This is been found out in the study of Gati and Asulin-Peretz (2011). The online assessment where can get it free on the online will helping individual to deliberating about their career choice. The score where get from the assessment will be interpret and recommend. It helps the individual to understand about their choice. Beside the counsellor can take the result of the assessment to make a better and professional interpretive feedback based on career expert's knowledge (Gati \& Asulin-Peretz, 2011). This was later support by John, Udofia, Udoh, and Anagbogu (2016) finding. In their study found that the students who went through the ecounselling guidance programme will have better experiences with the school counsellor. This is due to the student who done the assessment will have a basic understanding of their career choice which is career awareness. The school counsellor is there help them to resolve the specific problems with associated with career decision-making, planning and adjustment (John, Udofia, Udoh, \& Anagbogu, 2016). So the efficiency of the career counselling is increased.

Besides, the practitioner also can fully utilize the online interactive work spaces (Kettunen, et al. as cited in Bimrose, Kettunen, \& Goddard, 2015). The practitioner or the counsellor need to have professional development training where learn how to transfer their work into online system, it will properly help them to improve themselves in the online service (Bimrose, Kettunen, \& Goddard, 2015). Furthermore, the online counselling can have a transparent supervision because the communication between practitioner and client will be recorded and accessible for review by the supervisor. By using the recording supervisor can give practitioner the "real-time" and "real-context" case-conferencing; it will help the counsellor to improve their service by giving them strong support (Bimrose, Kettunen, \& Goddard, 2015).

\section{Challenges using Technology and Internet in Career Guidance and Counselling Self-limited Thinking}

While there are many advantages offered through the use of technology in career counselling services, there are also challenges that counsellors and career practitioners have to face when delivering such services to clients. One of these challenges are the close system way of thinking of certain individuals who perceive ICT in competing terms, and resist approaches that are new for fear that they would replace their systems or themselves (Bright, 2015). Hence instead of considering technology-assisted career counselling as either-or option or alternative service to the more traditional, face-to-face counselling, both counsellors and possible clients should be more open to the possibilities that both services can offer in enhancing counselling services. As Bright (2015) stated, the question that practitioners should be asking is not 'Who has control over what or how much?', but it is 'How do we get along together?' (p.28). The self-limited thinking of resisting to changes and uncertainties, according to Bright (2015), need to be addressed through counselling in order for the use of ICT in counselling to be more generally accepted among all. As Papakota (2016) explained, a key challenge to career counselling services and resources is to find ways to use technology as a 
INTERNATIONAL JOURNAL OF ACADEMIC RESEARCH IN BUSINESS AND SOCIAL SCIENCES Vol. 10, No. 11, 2020, E-ISSN: 2222-6990 @ 2020 HRMARS

supplement and a tool to extend human potential rather than restricting or replacing it. People who choose online counseling will be concern about the effectiveness of the online counseling. According to Glasheen, McMahon, Campbell, Rickwood, \& Shochet (2018), adult and the profession such as priciple of the school will concern about the effectiveness of online counseling compare to the faceto-face counseling. They "would like to see research first" before applying the service and also they think about the counselor will miss out the essential non-verbal cues where it will be obvious in traditional counseling session (Glasheen, McMahon, Campbell, Rickwood, \& Shochet, 2018).

\section{Lack of Awareness}

Another challenge to online services in career counselling and guidance is the lack of awareness and appeal of such services among especially the younger populations. In a study by Galliott (2017), he investigated on three factors that may be causing the lack of effectiveness in improving youth career certainty. Two of these factors are (1) the insufficient awareness of resources available targeted towards the youth and (2) the inability of the resources used (e.g. websites) to reach all students regardless of their school grade level and socioeconomic background. Galliott (2017) further explained that there is little awareness on the availability of career web resources among students which explains their unlikeliness to use such services. In terms of the uneven disperse of career web resources among all student groups, Galliot (2017) described that such websites have" selective audiences in relation to school-level students' characteristic whereby the level of exposure and access that students from each grade are receiving are different. Also, the nature of presentation of web resources may also influence how it attracts different groups of young adolescents which explain why a particular group of students from a similar school year-level (e.g. year 12) is more exposed to and attracted towards the services provided for them. In addition to this is also the likeliness of students from higher socioeconomic background, when compared to those from lower socioeconomic background, to search for help and support through online services. This is supported by the research of Vertsberger and Gati (2015), they state that the young adult facing the problem of career decision-making process and their intention to seek help from the available sources of support is weak. This is due to they do not understand how the available sources can help them to make career decisions. This problem is started when they in high school where does not know the available sources (Vertsberger \& Gati, 2015). Hence it can be said that online services and career web resources need to be improved on how it can better be presented and exposed to a wider range of groups which include individuals of all ages, status and backgrounds.

\section{Limited access of Internet and Digital Illiteracy}

Other challenges to online services are the inability of individuals with inadequate financial resources to opt or seek for access to career services. This is brought up in a study by Sampson and Makela (2014) who stated that society with the greatest economic and social risk are facing barriers when accessing for online resources and services due to the costs and charges from either technology purchase of monthly internet access. There is also a portion of the world's populations who has no access to internet which prevent them from receiving any technology-based career resources and services. As Sampson and Makela (2014) described, "even in the most economically advanced countries of the world there are still individuals with little to no access to the Internet" (p. 137), which says a lot about how online career services are also limited in their ability to reach all individuals. Ryan and Hopkins (2013) also describe that the young people from the low socioecnomic background 
INTERNATIONAL JOURNAL OF ACADEMIC RESEARCH IN BUSINESS AND SOCIAL SCIENCES Vol. 10, No. 11, 2020, E-ISSN: 2222-6990 @ 2020 HRMARS

will face challenges when they choose to enter university. This is due to they don't have the same opportunities same with others people. They didn't get the resources that help them to prepapre themselves (Ryan \& Hopkins, 2013).

Asides from this, digital literacy also has the ability to either enhance or impede individuals' access to technology. Hooley et al. (2010), as cited in Sampson and Makela (2014), claimed digital literacy to be a basis for individuals to interact confidently and comfortably with technology-based services that require distance access. Since digital literacy is an important aspect for both counsellors and clients when using online services, it hence remains a problem in providing such services where skills needed include writing in online text, email, chat and videoconferencing among others (Barak, 2003; Vuorinen \& Sampson, 2009, as cited in Sampson and Makela, 2014, p. 141). This is agreed by Osborn et al. (2014) who described the importance of counsellors to evaluate the ability and level of support that they client needs when using technology as a medium of communication and at the same time find ways that the clients can develop their computer skills. The statement was also found in Paterson, Laajala and Lehtela (2017). In their study found that some counselor were not confident to use the technical equipment. This is because they felt they lack of skills and knowledge about the device and technology. The lack of technical confidence inhibited the counselor and the young people to use online career counseling and participation in (Paterson, Laajala, \& Lehtela, 2017). Hence, while digital literacy is considered as main advantage to online career resources and services, it also remains as obstacles that need to be put attention to when providing such services.

\section{Quality of Information Provided and Presented}

The issues of quality and confidentiality of online career assessments and resources also limit the overall validity and usefulness of the services provided. Osborn et al. (2014) emphasized the prevalence of confidentiality, privacy and client safety, in addition to the quality of online assessment and appropriateness of a client to receive such services. Furthermore, Sampson and Makela (2014) stated, from a study by Barak (2003), that online career assessments vary in quality where only few of the web resources provide information on the validity of resources available. Osborn et al. (2014) also described the tendency of some career web resources in internet to unfairly emphasize on the positive aspects of the information, to not remove majority of the information that are not up-todate, while also present false data that may develop and promote negative perspectives such as stereotypes. This means that the quality of online career services have to be considered on the effectiveness of online assessments provided, also on how the information provided should be recent and updated, and presented without bias from all aspects that do not introduce any false data. Similarly, career sites should also not be crammed with too much information that uses highly technical terms especially when the resources are targeted towards students of age 15 to 17 years old (Sampson, Makela, 2014). Hence, career resources provided through the use of internet should be mindful on how information is presented and how it attracts its targeted audience. According to Gati and Asulin-Peretz (2011), the absence of expert human might be one of the problems for online career assessment or intervention. The online intervention is always standalone which mean it does not change and lack on on-going monitoring. This is different when doing individual counseling session because the counselor is there to monitor the interaction where avoid the lost happened in the session, if anything happen counselor can stop the process and bring the client back on track (Gati \& Asulin-Peretz, 2011). This quality of control is lacking in the online intervention. 
INTERNATIONAL JOURNAL OF ACADEMIC RESEARCH IN BUSINESS AND SOCIAL SCIENCES Vol. 10, No. 11, 2020, E-ISSN: 2222-6990 @ 2020 HRMARS

\section{Confidentiality and counsellors' Role}

Career counselling and resources practitioners also need to be wary when transferring clients' personal information through the internet. According to Sampson and Makela (2014), appropriate security measures need to be taken into utmost consideration and they can be precautionary actions such as "frequently changing passwords and using data encryption for transmissions over the Internet" (p. 140). Client's self-disclosure and confidentiality are also limited when clients choose to seek for online career services from public access points such as public libraries. Such method will encourage clients to attempt to interact with career practitioners amidst consistent distractions such as the "possibility of being observed, overheard or manipulated by another individual during a counselling session" (p. 141), hence affecting the efficiency of the counselling relationship. This is also possibly due to the lack of, or nonexistent of coded framework and standards that both counsellors and clients can abide to when using internet in career counselling services (Sampson Jr., J. P., \& Makela, J. P., 2014). Due to this reason, the use of online counselling among its practitioners is still vague which at the same time can affect the overall counselling relationship. Counsellors utilizing online services may face issues such as "blurring lines of career professionals' professional and personal lives" when the easy access to personal information can potentially leads to changes in the working relationship between a counsellor and his or her clients in the virtual world of internet (Kettunen et al., 2013; Osborn et al., 2011; Tunick et al., 2011, as cited in Sampson Jr., J. P., \& Makela, J. P., 2014, p. 143). Therefore, counsellors should be vigilant when ensuring the confidentiality of the counselling relationship and to be careful in separating their roles as professional counsellors and personal selves especially when delivering counselling services via the internet. Counsellor need to be confident to handle the issues of confidential, ethical, legal and privacy before they applied online career counseling (Glasheen, Campbell, \& Shochet, 2013). Counsellors also need to have a level of confident to understand the issues associated with online counseling (Glasheen, Campbell, \& Shochet, 2013).

\section{Clients Facing Extreme and Urgent Situations}

Another challenge to technology-based career counselling services is the lack of efficiencies when using these services on clients facing extreme issues, as well as the lack of competencies of counsellors and practitioners when facing these clients on urgent situations. According to Malone (2007); Ravis (2007), as cited in Sampson and Makela (2014), distance service delivery is considered inappropriate especially for individuals who are dealing with extreme issues such as high-level anxiety and severe depression or dysfunctionality. When a situation results in harm to the client or others, career counsellors and practitioners who provide distance delivery services are expected to take prompt action which hence require them to be knowledgeable and aware of local referral sources for such situations (Ravis, 2007; Vuorinen \& Sampson, 2009; Sampson et al., 1997, as cited in Sampson \& Makela, 2014). A similar situation to this is when questions raised during sessions require in-depth analysis by counsellors (e.g. choosing a major and extensive job search strategy) hence prompting them to refer these clients to face-to-face sessions (Haberstroh, Rowe, \& Cisneros, 2009). This is also supported by Sampson and Makela (2014) who described the appropriateness of certain clients to seek for face-to-face sessions especially for those who need immediate response or desire in-depth information sharing. Therefore as Sampson and Makela (2014), lack of competencies and information in counsellors when facing these situations may result to inadequate services and difficulties in making informed judgements when choosing a practitioner for referral cases. Counsellors need to 
INTERNATIONAL JOURNAL OF ACADEMIC RESEARCH IN BUSINESS AND SOCIAL SCIENCES Vol. 10, No. 11, 2020, E-ISSN: 2222-6990 @ 2020 HRMARS

ensure that their clients "have the technological, emotional, and mental capacities to engage in online counseling and develop clear procedures in cases of emergencies and technological failures" (ACA, 2005, as cited in Sampson, \& Makela, 2014, p. 35), which is agreed upon by Osborn et al. (2014) who claimed the importance of counsellors using synchronous tools such as online chatting to have backup plans in case of technological failures.

\section{Issues Disclose}

The issues of the client facing can be one of the challenges for online career counseling and guidance services. This were bought up in Howieson and Semple (2013) article. The study found out that minority pupils to be more active in their career planning by seeking direct with professional career guidance rather than using the accessing of career website. This were majority those students who were at risk of not achieving positive post school destinations (Howieson \& Semple, 2013). In Howieson report also state that online career system is one of an additional method of delivery the service but it is not the replacement of face-to-face support. Issues of the client as one of the problem for online counseling service are agreed by Glasheen, Shochet, and Campbell (2016). According to Glasheen, Shochet, and Campbell (2016) stated that if student who using online counseling they were more likely to discuss about sensitive issues such as sexuality compare to career issues. The result found out in their study showed students who facing psychological distress will be more intention to seek online help (Glasheen, Shochet, \& Campbell, 2016). It was due to the disinhibition effect of online communication where will allow people to discuss their concern without worry about the stigmatizing issues (Suler, 2005; Fenichel et al., 2002, as cited in Glasheen, Shochet, and Campbell, 2016 , p. 116). By using the online counseling service they will be help in control the visibility in the school and society regarding the sexual issues that they facing. This was also support by Mishna, Bogo, and Sawyer (2015) study. The result showed that client are more likely to disclose sensitive and private information in online counseling compare to face-to-face counseling service such as social anxiety and sexuality issues. They will be different in telling the issues in both services. There will be lot thing come up in the online session and this is because the client feel easier to disclose and they won't feel the counselor is judging them due to they can't see their reaction (Mishna, Bogo, \& Sawyer, 2015). The same result show by Zeren (2015) study. The people will be easier to disclose by using the online counseling service. They feel more comfortable to disclose themselves with more sensitive issues in the online session compare to the face-to-face session. However, in Zeren (2015 study also find out the relationship between the counselor and the client in the online session will be slightly different with the face-to-face session. The satisfaction of online counseling will not as much as the traditional session (Zeren, 2015).

However there is some different view in the study of Adebowale and Popoola (2011). In their study found that students identified potential online guidance and counselling needs as being mainly related to academic or educational interests; specifically, career planning, problem-solving skills and acquiring effective study skills. The online counseling need of university student is different with the secondary students. The university student use online counseling for the career planning. This is probably due to the age of the student where university student are more recognized that their next step of their life would be building their career (Adebowale \& Popoola, 2011). This is supported by the study of Omeje, Eze, and Egeonu (2016), in the study stated that the highest rate of using of ecounselling career service is the final year student where is unemployed. It compare to the others 
INTERNATIONAL JOURNAL OF ACADEMIC RESEARCH IN BUSINESS AND SOCIAL SCIENCES Vol. 10, No. 11, 2020, E-ISSN: 2222-6990 @ 2020 HRMARS

individual who already employed or working, the e-counseling career service or information is not fully utilized (Omeje, Eze, \& Egeonu, 2016).

\section{Implication}

In order to enhance and improve the use of internet and technology in career counselling, it is important for career practitioners and counsellors to bring their attention to not only providing training for its users. While it is important for both counsellors and clients to gain and improve their computer and digital literacy skills, it is as important too for career services, sites and resources to be presented and designed appropriately to extract the full potential of ICT (Bright, 2015). This is also agreed by Galliott (2017) where he implied how the nature of presentation of career resources influences how it attracts different group of individuals and this is especially important when such services has a targeted audience that they wish to approach. Besides that, according to Bright (2015), working with developers in producing websites, apps and interactive online learning environments can help to encourage more career practitioners to be involved in the online services, which will hence help to enhance and improve the services delivered. System usability and interface design, as further explained by Bright (2015), is important in making sure that the information provided are always up-to-date so that users are able to perceive the information correctly. Hence, it is clear that the quality of information and how this information is presented through career services and resources should go hand-in-hand when considering ways to improve the services and to attract more practitioners and users.

In terms of providing additional training in computer and ICT skills, Sampson and Makela (2014) described the importance of counsellors and practitioners to consider how online services are conducted according to ethical standards and core ethical principles of counselling and guidance professionals. According to Martin (2010), as cited in Sampson and Makela (2014), in a case where the ethical standards do not directly address the specific use of ICT, "counseling and guidance professionals should be encouraged to thoughtfully consider the implications of using that technology in terms of how the core ethical principles of their profession might apply to this new situation" (p. 144). These ethical standards may touch on issues such as confidentiality, availability of use support, assessment validity and so forth. Hence, as further explained by Sampson and Makela (2014), the growing use and prevalence of internet among the society prompted the development and improvement of training resources that are targeted for career counsellors and practitioners. These training resources can include those such as case studies on technology access and internet resources, where they will help practitioners to better "understand the nuances in applying ICT standards to counselling and guidance practice (Sampson, \& Makela, 2014, p. 145).

As a provision for a future that is far less stable and predictable in many aspects such as career, the ICT is especially important for counsellors and practitioners to fully utilize so to make sure that all individuals are properly prepared for any rapid life changes. Also according to Gati et al. (2001), as cited by Galliott (2017), online career guidance is more likely to be effective when combined its use with face-to-face counselling. Hence, it is not wise for counsellors to consider online services as solely an alternative, either-or option for face-to-face services, but instead to enhance the overall counselling experiences by combining the two methods of counselling approaches. Therefore, counsellors and practitioners need to be active agents when promoting these services to their targeted audience via schools, or if possible, as Galliott (2017) suggested, through mass media so that counsellors, through these services, can reach out to all individuals especially those from lower 
INTERNATIONAL JOURNAL OF ACADEMIC RESEARCH IN BUSINESS AND SOCIAL SCIENCES Vol. 10, No. 11, 2020, E-ISSN: 2222-6990 @ 2020 HRMARS

socioeconomic backgrounds and with limited financial resources, as well as for young people who have restricted access to online career services. As Sampson, Dozier and Colvin (2011) stated, as cited by Sampson and Makela (2014), "equity of access to career interventions is a social justice issue" (p. 138) and it is a counsellors and practitioner's responsibility to recognize the lack of exposure and limited access to career sources that some individuals are facing. In conclusion, it is prevalent for counsellors to extend their services to all individuals and to be mindful on the importance of both counselling methods which are online and face-to-face methods. As Friedman (2016) introduced, as cited in Lent (2008), the empathy skills are useful for counsellors to better prepare clients for the foreseeable future where these skills encourage counsellors to develop expertise in both high-tech (e.g. technology use when performing self-assessments) and high-touch (or the human skills that counsellors possessed) domains.

\section{Conclusion}

Career counselling services via online technology is now a growing field that is slowly receiving attention from researchers, career practitioners, counsellors and other professionals. The use of ICT has become an important aspect in the lives of most living individuals now hence it is to no surprise that such tool is beneficial when used as a mediator in career counselling services. Hence this review paper covered on the topic of internet and technology utilization in career counselling in terms of its current application, advantages and challenges when providing these services.

This paper discussed on how technology-based career counselling is applied either through its use during virtual sessions with clients and career assessments, as well as for any individuals who are seeking for career information or for job search purposes. From the literatures reviewed, reviewer was able to discover the advantages and challenges of using technology in career counselling. In terms of advantages, the use of technology and internet in career counselling services emphasized on how they are able to expand their services to all individuals more quickly, then on the constant access and immediate response by counsellors, the services as a generator of information gathering and finally on the use of audio-visual that enhance online services. Last but not least, the challenges that cyber-based career counselling services are facing are also discussed where these challenges are those such as self-limited thinking, lack of awareness, limited access of internet and digital illiteracy, quality of information provided and presented, confidentiality and counsellor's professional role, and finally on clients facing extreme issues. Advantages is important to predict the usefulness of the techniques applied. In the paper we know that the technology-based career counselling provided few advantages to counsellor and their clients. However, the challenges is the issues that both counsellor and client have to look on where to maintain the quality of the counselling session.

In conclusion, technology-based career counselling is one of the ways to applied in career counselling since there is several advantages in technology-based career counselling showed in the literature review. However, the challenges of the technology-based career counselling need to be known and aware by the career counsellor to avoid unnecessary issues happen. This paper also discussed on the implications of this study on career counsellors and practitioners, educators, and researchers.

\section{Acknowledement}

This paper is funded by FRGS 2018 research grant by Ministry of Education. 
INTERNATIONAL JOURNAL OF ACADEMIC RESEARCH IN BUSINESS AND SOCIAL SCIENCES

Vol. 10, No. 11, 2020, E-ISSN: 2222-6990 @ 2020 HRMARS

\section{References}

Adebowale, O. F., \& Popoola, B. I. (2011). Prospects and challenges of online guidance and counselling service in a Nigerian university. International Journal for the Advancement of Counselling, 33(1), 64-78. http://dx.doi.org/10.1007/s10447-010-9109-x

Amritesh, Misra, S. C., \& Chatterjee, J. (2014). Emerging scenario of online counseling service in India:A case of e-government intervention. Transforming Government: People, Process and Policy, 8(4), 569-596. http://dx.doi.org/ 10.1108/TG-10-2013-0043

Anthony, K. (2015). Training therapists to work effectively online and offline within digital culture. British Journal of Guidance \& Counselling, 43(1), 36-42. http://dx.doi.org/10.1080/03069885.2014.924617

Argyris, Y. E., \& Xu, J. (2016). Enhancing self-efficacy for career development in faceook. Computers in Human Behavior, 55, 921-931. http://dx.doi.org/10.1016/j.chb.2015.10.023

Bimrose, J., Kettunen, J., \& Goddard, T. (2015). ICT - the new frontier? Pushing the boundaries of careers practice. British Journal of Guidance \& Counselling, 4(1), 8-23. http://dx.doi.org/10.1080/03069885.2014.975677

Bright, J. E. H. (2015). If you go down to the woods today you are in for a big surprise: Seeing the wood for the trees in online delivery of career guidance. British Journal of Guidance and Counselling, 43(1), 24-35. http://dx.doi.org/10.1080/03069885.2014.979760

Galliott, N. (2017). Online career guidance: Does knowledge equate to power for high school students? Journal of Psychologists and Counsellors in Schools,27(2), 190-207. http://dx.doi.org/10.1017/jgc.2017.7

Gati, I., \& Asulin-Peretz, L. (2011). Internet based self-help career assessments and interventions: Challenges and implications for evidence-based career counseling. Journal of Career Assessment, 259-273. http://dx.doi.org/10.1177/1069072710395533

Glasheen, K. J., Shochet, I., \& Campbell, M. A. (2016). Online counselling in secondary schools: would students seek help by this medium? British Journal of Guidance \& Counselling, 44(1), 108-122. http://dx.doi.org/10.1080/03069885.2015.1017805

Glasheen, K., Campbell, M. A., \& Shochet, I. (2013). Opportunities and challenges: School guidance counsellors' perceptions of counselling students online. Australian Journal of Guidance and Counselling, 23(2), 222-235. http://dx.doi.org/10.1017/jgc.2013.15

Glasheen, K., McMahon, M., Campbell, M., Rickwood, D., \& Shochet, I. (2018). Implementing online counselling in australian secondary schools: What principals think. Int J Adv Counselling, 1425. http://dx.doi.org/10.1007/s10447-017-9307-x

Haberstroh, S., Rowe, S., \& Cisneros, S. (2009). Implementing virtual career counselling and advising at a major university. Journal of Cases on Information Technology, 11(3), 31-44. http://dx.doi.org/10.4018/jcit.2009070103

Harris-Bowlsbey, J. (2013). Computer-assisted career guidance systems: A part of NCDA history. The Career Development Quarterly, 61, 181-185. http://dx.doi.org/10.1002/j.21610045.2013.00047.x

Howieson, C., \& Semple, S. (2013). The impact of career websites: what's the evidence?British Journal of Guidance \& Counselling, 41(3), 287-301.

http://dx.doi.org/10.1080/03069885.2013.773960 
INTERNATIONAL JOURNAL OF ACADEMIC RESEARCH IN BUSINESS AND SOCIAL SCIENCES Vol. 10, No. 11, 2020, E-ISSN: 2222-6990 @ 2020 HRMARS

John, I. E., Udofia, N.-A., Udoh, M. A., \& Anagbogu, M. A. (2016). Development of e-career guidance programme for secondary schools in Akwa Ibom State. Educational Media International, 53(4), 298-312. http://dx.doi.org/10.1080/09523987.2016.1254886

Lent, R. W. (2018). Future of work in the digital world: Preparing for instability and opportunity. Career Development Quarterly, 66(3), 205-219. http://dx.doi.org/10.1002/cdq.12143

Mishna, F., Bogo, M., \& Sawyer, J.-L. (2015). Cyber counseling: Illuminating benefits and challenges. Clinical Social Work Journal, 43(2), 169-178. http://dx.doi.org/10.1007/s10615-013-0470-1

Nota, L., Santilli, S., \& Soresi, S. (2016). A life-design-based online career intervention for early adolescents: Description and initial analysis. Career Development Quarterly, 64(1), 4-19. http://dx.doi.org/10.1002/cdq.12037

Omeje, J. C., Eze, J. U., \& Egeonu, D. C. (2016). Utilization of e-counseling in career information dissemination among undergraduates of federal universities in South East Nigeria. Sage Open, 1-8. http://dx.doi.org/10.1177/2158244016655586

Osborn, D. S., Kronholz, J. F., Finklea, J. T., \& Cantonis, A. M. (2014). Technology savvy career counselling. Canadian Psychology, 55(4), 258-265. http://dx.doi.org/ 10.1037/a0038160

Papakota, A. (2016). Career counselling development: A case study of an innovative career counselling tool. Industry and Higher Education, 30(5), 327-333. http://dx.doi.org/10.1177\%2F0950422216664422

Paterson, S. M., Laajala, T., \& Lehtela, P. -L. (2017). Counsellor students' conceptions of online counselling in Scotland and Finland. British Journal of Guidance \& Counselling. http://dx.doi.org/10.1080/03069885.2017.1383357

Poncy, G., Kim, M., Ramos, K., \& Lopez, F. G. (2017). Career planning confidence among facebook user: Contributions of adults attachment security and authenticity. Journal of Career Assessment, 1-17. http://dx.doi.org/10.1177/1069072717723094

Ryan, N. J., \& Hopkins, S. (2013). Combining social media and career development learning: An intensive tertiary preparation programme for disadvantaged youth. Australian Journal of Career Development, 22(3), 107-111. http://dx.doi.org/10.1177/1038416213505274

Sampson, Jr., J. P., \& Makela, J. P. (2014). Ethical issues associated with information and communication technology in counselling and guidance. International Journal for Educational and Vocational Guidance, 14(1), 135-148. http://dx.doi.org/10.1007/s10775-013-9258-7

Vertsberger, D., \& Gati, I. (2015). Career decision-making difficulties and help-seeking among Israeli young adults. Journal of Career Development, 43(2), 145-159.

http://dx.doi.org/10.1177/0894845315584162

Wessels, C. J. J., \& Diale, B. M. (2017). Facebook as an instrument to enhance the career construction journeys of adolescent learners. South African Journal of Education, 37(4), 1470. http://dx.doi.org/10.15700/saje.v37n4a1470

Wong, K., Kwan, R., Leung, K., \& Wang, F. L. (2014). Facebook's potential for personal, social, academic and career development for higher education students. Int. J. Innovation and Learning,, 16(2), 203-220. http://dx.doi.org/10.1504/IJIL.2014.064367

Zeren, S. G. (2015). Face-toface and online counseling:Client problems and satisfaction. Education and Science, 40, 127-141. http://dx.doi.org/10.15390/EB.2015.46

Zainudin, Z. N., Yusof, Y. M., Hassan, S. A., Alias, B. S. (2019). The effectiveness of cybertherapy for the introvert and extrovert personality traits, Malaysian Journal of Medicine and Health Sciences, 15. 